ISSN: 1858-4837; E-ISSN: 2598-019X

Volume 16, Nomor 2 (2021),

https://jurnal.uns.ac.id/region

DOI: 10.20961/region.v16i2.25772

\title{
Analisis efektivitas mitigasi bencana kebakaran di Kota Surakarta
}

\author{
The effectiveness analysis of fires mitigation in Surakarta City
}

\author{
M Fauzi ${ }^{1}$, N Miladan ${ }^{1}$, dan R P Utomo ${ }^{1}$ \\ ${ }^{1}$ Program Studi Perencanaan Wilayah dan Kota, Fakultas Teknik, Universitas Sebelas \\ Maret
}

Corresponding author's email: muhammadfz777@gmail.com

\begin{abstract}
Abstrak. Kota Surakarta mengalami peningkatan kejadian kebakaran pada tiap tahunnya. Kejadian kebakaran tertinggi tercatat pada tahun 2017 dengan total 78 kali peristiwa. Dalam menanggulangi peningkatan kejadian kebakaran ini, pemerintah kota Surakarta berupaya untuk meningkatkan sistem mitigasi yang ada. Tujuan dari penelitian ini adalah untuk mengetahui efektivitas komponen mitigasi bencana kebakaran di kota Surakarta. Komponen mitigasi pada penelitian ini yaitu pasokan air, hidran, pos pemadam, aksesibilitas, penginformasian bencana, dan peringatan dini. Metode pengumpulan data yang digunakan berupa pengumpulan data primer untuk mengetahui persebaran dan lokasi dari komponen mitigasi, dan pengumpulan data sekunder untuk mengetahui kualitas dari masing-masing komponen mitigasi. Teknik analisis yang digunakan berupa teknik analisis spasial, teknik analisis diskriptif dan teknik analisis skoring untuk mengetahui nilai dari masing-masing komponen yang ada. Hasil penelitian menunjukan bahwa tingkat efektivitas komponen mitigasi kebakaran di kota Surakarta memiliki kategori kurang efektif. Hal ini disebabkan karena masih terdapat kuantitas maupun kualitas dari komponen mitigasi bencana yang masih dalam kategori rendah dan sedang. Seperti pada komponen mitigasi struktural yang berupa kualitas pasokan air, kuantitas atau jumlah hidran yang bisa digunakan, kuantitas atau perlengkapan pada masing-masing pos pemadam, dan waktu tanggap bencana yang masih dalam kategori sedang karena belum mampu memenuhi kebutuhan kota Surakarta secara menyeluruh. Pada komponen mitigasi non struktural berupa penginformasian dalam bentuk peta dan peringatan dini masih dalam kategori sedang dan rendah karena belum adanya peta penginformasian dan peta persebaran proteksi. Selain itu bentuk peringatan dini yang dimiliki kota Surakarta masih minim.
\end{abstract}

Received: December 03, 2018; Accepted: December 20, 2018; Available online: July 15, 2021

Copyright $\odot$ 2021, REGION: Jurnal Pembangunan Wilayah dan Perencanaan Partisipatif 
Kata Kunci: Efektivitas; Kebakaran; Komponen; Mitigasi

\begin{abstract}
Fires in the city of Surakarta have increased every year. The highest fires was recorded in 2017 with a total of 78 incidents. To overcome these increasing fires, Surakarta's Government improves the existing mitigation system. The purpose of this research is to determine the effectiveness of fires mitigation component in Surakarta. Mitigation components in this research are water supply, hydrant, fire station, accessibility, disaster information, and early warning. The data collection method used primary data collection to determine the distribution and location of mitigation components, and secondary data collection to determine the quality of each mitigation components. The analysis employed special, description, and scoring analysis to determine the value of each component. The result shows that the fires mitigation component in Surakarta is less effective, since the quality and quantity of fire mitigation component is at low and moderate level. As in structural mitigation component, the water supply quality, the number of hydrants, the equipment at each fire station, and the response are still in moderate level because they haven't been able to cover the safety in Surakarta. In non-structural mitigation component, the information in the form of maps and early warning are still at low and moderate level because there is no information and protection distribution maps. Besides that, early warning in Surakarta is still minimum.
\end{abstract}

Keywords: Component; Effectiveness; Fire; Mitigation

\title{
1. Pendahuluan
}

Menurut Ramli [1], kebakaran merupakan api yang tidak dapat dikendalikan. Standar Nasional Indonesia (SNI) 03-3985-2000 mencantumkan pengertian kebakaran adalah sebuah fenomena yang disebabkan oleh suatu bahan yang mencapai temperatur krisis dan bereaksi secara kimia dengan oksigen (sebagai contoh) yang menghasilkan panas, nyala api, cahaya, asap, uap air, karbon monoksida, karbondioksida, atau produk dan efek lain [2]. Kebakaran merupakan salah satu jenis bencana yang memiliki peningkatan risiko dalam pengaruhnya dengan perkembangan kota. Hendarto dalam Ariobowo [3], menjelaskan inti dari perkembangan kota adalah pertumbuhan atau perubahan secara sosial ekonomi, sosial budaya, dan fisik. Selain itu Ramli [1] menyebutkan listrik adalah salah satu contoh penyebab yang terdapat dalam faktor-faktor terjadinya kebakaran. Kaitan antara listrik sebagai pemicu kebakaran dengan perkembangan kota adalah berkembangnya suatu kota identik dengan bertambahnya jumlah penduduk dan peningkatan perekonomian. Pertambahan ini mengakibatkan meningkatnya kepadatan penduduk yang mengarah pada peningkatan kepadatan bangunan serta peningkatan aktivitas. Peningkatan tersebut jika dilihat dari sudut pandang kebencanaan mengakibatkan persentase kesalahan teknis yang semakin meningkat sehingga dapat memicu terjadinya suatu bencana. Salah satunya adalah penggunaan listrik yang semakin meningkat dan berlebih mengakibatkan meningkatnya risiko terjadinya konsleting lebih tinggi yang dapat memicu terjadinya kebakaran. Dengan demikian, perlu adanya suatu cara untuk mengurangi tingkat risiko, yaitu risiko kebakaran. 
Menurut Peraturan Pemerintah No. 21 Tahun 2008 mengenai penyelenggaraan penanggulangan bencana, mitigasi merupakan bentuk serangkaian upaya untuk mengurangi risiko bencana baik dalam bentuk struktural maupun non struktural dalam menghadapi ancaman bencana [4]. Dalam rangka mengurangi tingkat risiko terjadinya bencana, perlu adanya perencanaan yang matang berupa peningkatan mitigasi sehingga mampu mengurangi tingkat risiko kejadian kebakaran.

Menurut data BPBD Kota Surakarta [5], pada tiap tahunnya kejadian kebakaran di Kota Surakarta mengalami kenaikan. Tercatat pada BPBD terdapat peningkatan jumlah kebakaran pada tahun 2010 sebanyak 28 kali peristiwa, tahun 2011 terjadi 37 kali peristiwa, tahun 2012 terjadi 46 kali peristiwa, dan pada tahun 2013 terjadi 65 kali peristiwa. Menurut data Dinas Pemadam Kebakaran [6], pada tahun 2017 menjadi puncak kejadian kebakaran paling tinggi. Tercatat peristiwa kebakaran meningkat menjadi 78 kali peristiwa kebakaran.

Pada dasarnya pemerintah Kota Surakarta sudah melakukan berbagai upaya untuk mengurangi tingkat risiko kebakaran. Tercatat oleh Dinas Pemadam Kebakaran [7] menambah jumlah hidran di Kota Surakarta sebanyak 78 hidran yang berfungsi sebagai sumber air untuk melakukan pemadaman. Pada tahun 2018, juga terdapat penambahan pos pemadam yang pada semula berjumlah tiga pos pemadam menjadi empat pos pemadam yang berada di Kelurahan Sumber. Dengan usaha pemerintah Kota Surakarta dalam peningkatan mitigasi yang ada, peneliti akan mengkaji mengenai penilaian terhadap efektivitas mitigasi sehingga diketahui tingkat efektivitas mitigasi bencana kebakaran di Kota Surakarta.

\section{Metode}

Pendekatan penelitian yang digunakan adalah pendekatan deduktif. Pendekatan ini bersifat kuantitatif. Teknik pengumpulan data yang digunakan berupa teknik pengumpulan data primer dan data sekunder. Proses pengumpulan data primer berupa observasi lapangan dan wawancara untuk mengetahui lokasi serta kualitas dari komponen proteksi kebakaran. Pengumpulan data sekunder dilakukan dengan studi literatur dan mengumpulkan data tertulis yang sudah disusun oleh lembaga pemerintahan daerah, yaitu dinas pemadam kebakaran. Dari hasil pengumpulan data akan dilakukan pemetaan menggunakan perangkat (tools) ArcGIS dan analisis skoring untuk mengetahui tingkat efektivitas dari komponen mitigasi bencana kebakaran di Kota Surakarta. Penentuan indikator efektivitas menggunakan penjelasan menurut Hidayat dalam Darinsyah [13]. Efektivitas merupakan sebuah tolak ukur yang menyatakan seberapa jauh target yang ditentukan (kuantitas, kualitas dan waktu) telah tercapai. Semakin besar persentase target yang ditentukan, semakin tinggi tingkat efektivitasnya sehingga indikator dan parameter dari variabel yang digunakan dalam penelitian ini adalah sebagai berikut (lihat Tabel 1). 
Tabel 1. Indikator parameter variabel $[7,12,14,15]$.

\begin{tabular}{|c|c|c|c|c|c|}
\hline \multirow[b]{2}{*}{ Variabel } & \multirow{2}{*}{\multicolumn{2}{|c|}{$\begin{array}{c}\text { Indikator } \\
\text { Kualitas(KL), } \\
\text { Kuantitas(KN),Waktu(W) }\end{array}$}} & \multicolumn{3}{|c|}{ Parameter } \\
\hline & & & \multirow{2}{*}{$\begin{array}{c}\text { Tinggi } \\
\text { Terdapat sumber } \\
\text { air alami dan } \\
\text { buatan yang bisa } \\
\text { digunakan }\end{array}$} & \multirow{2}{*}{$\begin{array}{c}\text { Sedang } \\
\text { Terdapat sumber } \\
\text { air alami dan } \\
\text { buatan namun } \\
\text { tidak dapat } \\
\text { digunakan dengan } \\
\text { lancar } \\
\end{array}$} & \multirow{2}{*}{$\begin{array}{c}\text { Rendah } \\
\text { Tidak terdapat } \\
\text { sumber air alami } \\
\text { maupun buatan }\end{array}$} \\
\hline Pasokan air & KL & $\begin{array}{c}\text { Sumber (alami dan } \\
\text { atau buatan) }\end{array}$ & & & \\
\hline \multirow[t]{2}{*}{ Hidran } & KL & $\begin{array}{c}\text { Jangkauan hidran } 1 \\
\text { km }\end{array}$ & $\begin{array}{c}\text { Cakupan hidran } \\
66,7 \%-100 \%\end{array}$ & $\begin{array}{c}\text { Cakupan hidran } \\
33,4 \%-66,6 \%\end{array}$ & $\begin{array}{c}\text { Cakupan hidran } \\
\text { 0\%-33,3\%. }\end{array}$ \\
\hline & KN & $\begin{array}{c}\text { Jumlah hidran yang } \\
\text { berfungsi }\end{array}$ & $\begin{array}{c}\text { Hidran yang } \\
\text { berfungsi } 66,7 \%- \\
100 \% .\end{array}$ & $\begin{array}{c}\text { Hidran yang } \\
\text { berfungsi } 33,4 \%- \\
66,6 \% .\end{array}$ & $\begin{array}{l}\text { Hidran yang } \\
\text { berfungsi 0\%- } \\
\text { 33,3\%. }\end{array}$ \\
\hline \multirow[t]{2}{*}{ Pos pemadam } & KN & $\begin{array}{l}\text { Ketersediaan } \\
\text { peralatan } \\
\text { operasional dan } \\
\text { komponen } \\
\text { kendaraan } \\
\text { operasional }\end{array}$ & $\begin{array}{l}\text { Tersedia semua } \\
\text { peralatan } \\
\text { operasional dan } \\
\text { komponen } \\
\text { kendaraan } \\
\text { operasional }\end{array}$ & $\begin{array}{c}\text { Tersedia sebagian } \\
\text { peralatan } \\
\text { operasional dan } \\
\text { komponen } \\
\text { kendaraan } \\
\text { operasional }\end{array}$ & $\begin{array}{l}\text { Tidak tersedia } \\
\text { atau hanya } \\
\text { peralatan } \\
\text { operasional atau } \\
\text { komponen } \\
\text { kendaraan } \\
\text { operasional }\end{array}$ \\
\hline & KL & $\begin{array}{l}\text { Jangkauan pos } \\
\text { pemadam 2,5 km }\end{array}$ & $\begin{array}{c}\text { Jangkauan pos } \\
\text { pemadam sebesar } \\
66,7 \%-100 \%\end{array}$ & $\begin{array}{c}\text { Jangkauan pos } \\
\text { pemadam sebesar } \\
33,4 \%-66,6 \%\end{array}$ & $\begin{array}{c}\text { Jangkauan pos } \\
\text { pemadam } \\
\text { sebesar } 0 \%-33,3 \%\end{array}$ \\
\hline Aksesibilitas & $\mathbf{W}$ & $\begin{array}{c}\text { Waktu tanggap } \\
\text { bencana (1) } 5 \text { menit } \\
\text { penentuan lokasi dan } \\
\text { persiapan (2) } 5 \text { menit } \\
\text { perjalan ke lokasi (3) } \\
5 \text { menit menggelar } \\
\text { peralatan }\end{array}$ & $\begin{array}{c}\text { Waktu tanggap } \\
\text { sesuai dengan } \\
\text { ketentuan dan } \\
\text { jangkauan } \\
\text { mencapai } 66,7 \%- \\
\text { 100\% luas Kota } \\
\text { Surakarta } \\
\end{array}$ & $\begin{array}{c}\text { Jangkauan waktu } \\
\text { tanggap mencapai } \\
33,4 \%-66,6 \% \text { luas } \\
\text { Kota Surakarta }\end{array}$ & $\begin{array}{c}\text { Jangkauan waktu } \\
\text { tanggap } \\
\text { mencapai 0\%- } \\
\text { 33,3\% luas Kota } \\
\text { Surakarta }\end{array}$ \\
\hline $\begin{array}{l}\text { Penginformasi- } \\
\text { an bencana }\end{array}$ & KL & $\begin{array}{l}\text { Peta risiko bencana } \\
\text { dan peta persebaran } \\
\text { sarpras pemadam } \\
\text { kebakaran }\end{array}$ & $\begin{array}{l}\text { Terdapat peta } \\
\text { risiko dan peta } \\
\text { persebaran } \\
\text { sarana dan } \\
\text { prasana bencana }\end{array}$ & $\begin{array}{l}\text { Hanya ada satu } \\
\text { peta dalam } \\
\text { penginformasian } \\
\text { bencana }\end{array}$ & $\begin{array}{c}\text { Tidak adanya peta } \\
\text { dalam } \\
\text { penginformasian } \\
\text { bencana }\end{array}$ \\
\hline Peringatan Dini & KL & $\begin{array}{c}\text { Peringatan dini yang } \\
\text { berfungsi kepada } \\
\text { masyarakat dan } \\
\text { Damkar }\end{array}$ & $\begin{array}{c}\text { Adanya } \\
\text { peringatan dini } \\
\text { kepada } \\
\text { masyarakat } \\
\text { sekitar dan } \\
\text { pemanggilan } \\
\text { bantuan ke pos } \\
\text { pemadam }\end{array}$ & $\begin{array}{c}\text { Adanya peringatan } \\
\text { dini yang ditujukan } \\
\text { hanya kepada salah } \\
\text { satu (masyarakat } \\
\text { sekitar atau pos } \\
\text { pemadam } \\
\text { kebakaran)/ masih } \\
\text { sedikit }\end{array}$ & $\begin{array}{l}\text { Belum adanya } \\
\text { peringatan dini } \\
\text { kepada } \\
\text { masyarakat dan } \\
\text { pos pemadam }\end{array}$ \\
\hline
\end{tabular}

Kerangka analisis pada penelitian ini adalah sebagai berikut (lihat Gambar 1). 


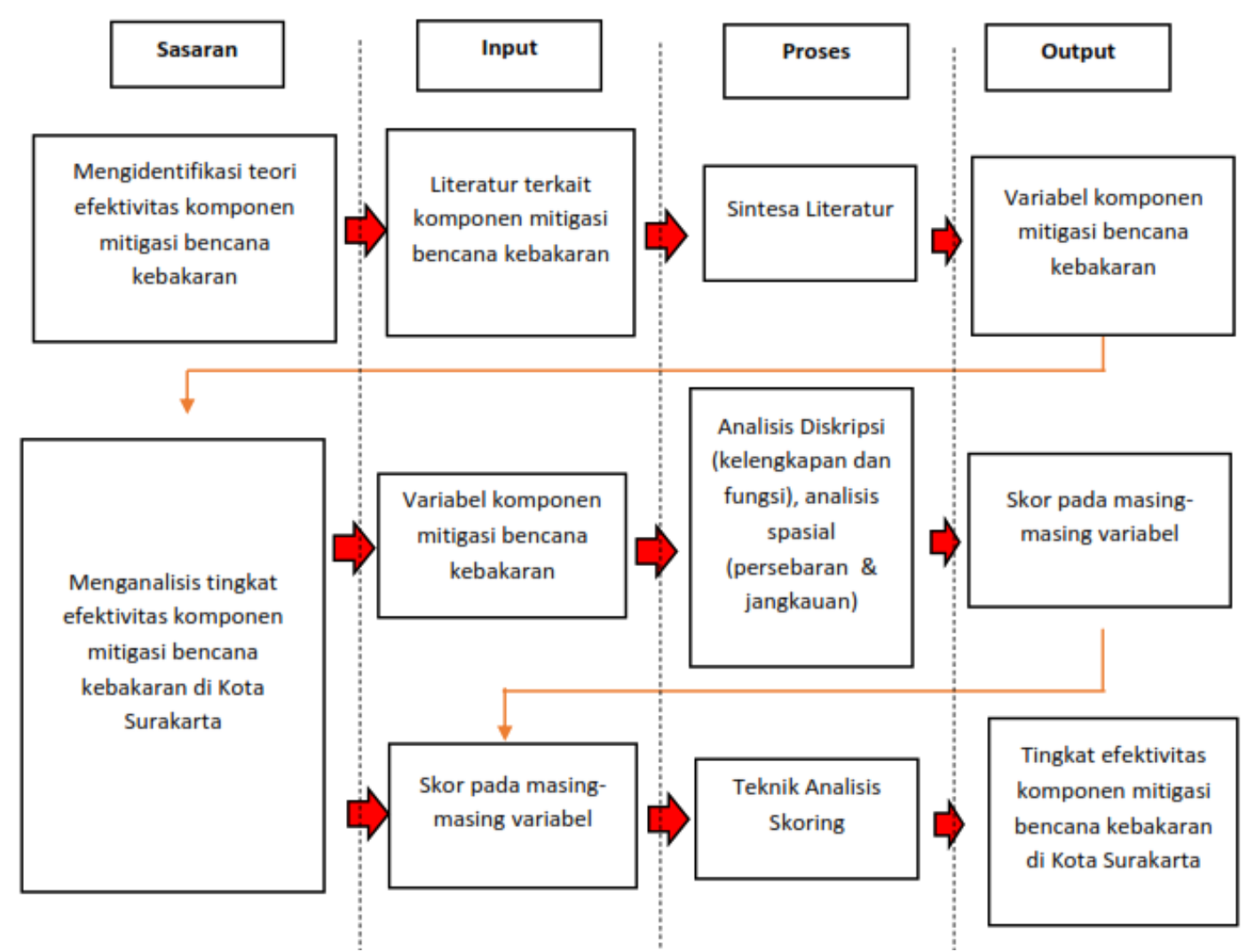

Gambar 1. Kerangka analisis penelitian.

Kerangka analisis pada penelitian ini didasarkan pada dua sasaran penelitian, yang pertama adalah untuk mengidentifikasi teori efektivitas komponen mitigasi bencana kebakaran sehingga didapatkan variabel yang dibutuhkan dalam penelitian ini. Kedua, menganalisis tingkat efektivitas dari masing-masing komponen untuk mengetahui nilai efektivitas komponen mitigasi bencana kebakaran di Kota Surakarta.

\section{Hasil penelitian dan pembahasan}

\subsection{Mitigasi struktural}

3.1.1 Sumber air. Sesuai dengan Permen PU No 20/PRT/M/2009, terdapat dua jenis pasokan air dalam menanggulangi bencana kebakaran, yakni sumber air alami dan sumber air buatan [12]. Hasil pengolahan data yang didapatkan dari pihak PDAM dan Damkar, sumber air yang digunakan di Kota Surakarta berupa sumber air buatan dalam bentuk hidran yang sudah disediakan oleh Dinas PDAM. 


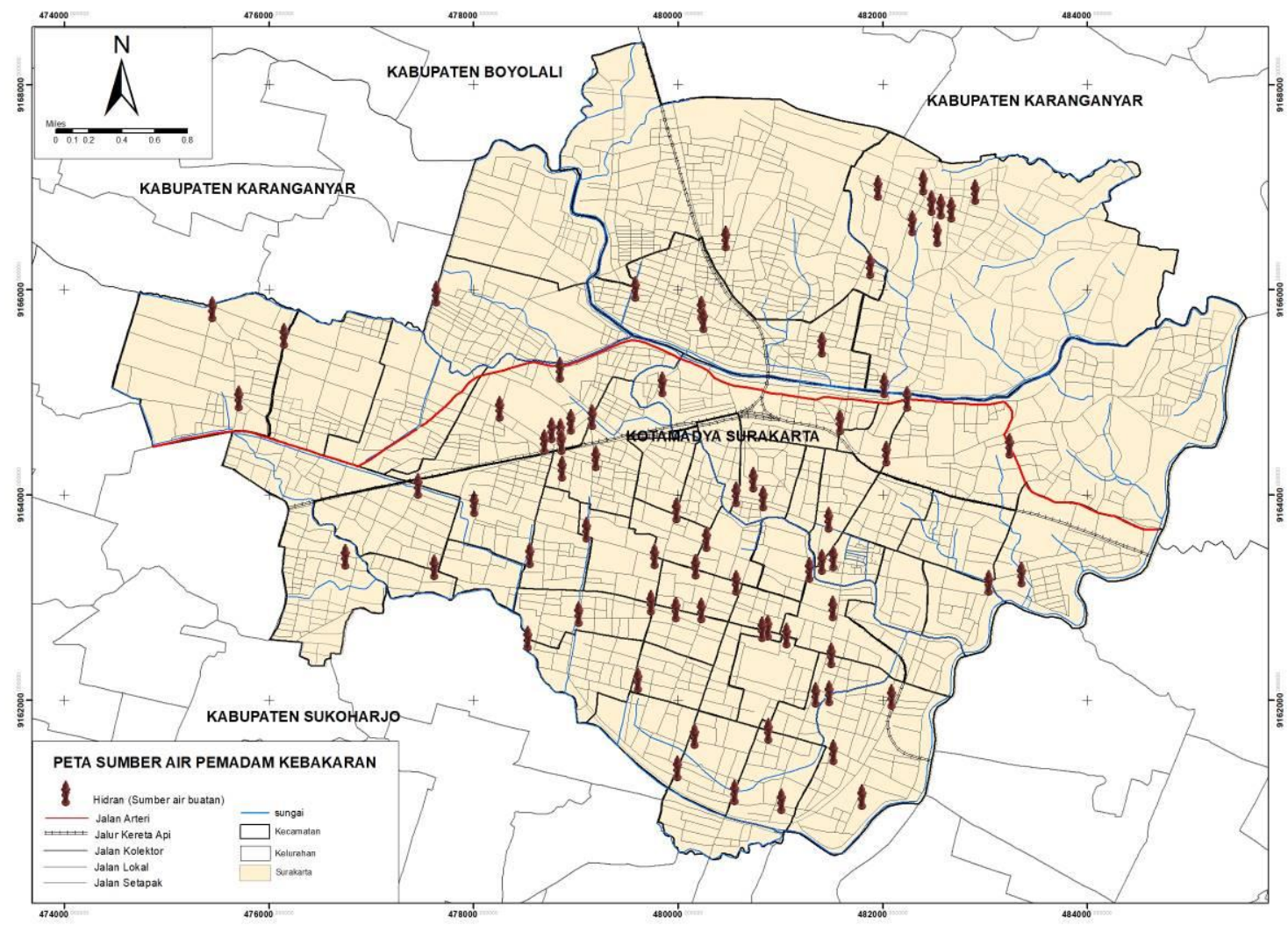

Gambar 2. Peta sumber air pemadam kebakaran.

Hidran yang sudah disediakan oleh PDAM tersebar merata di Kota Surakarta (lihat Gambar 2). Pada dasarnya untuk sumber air alami yang ada berupa sungai memiliki kualitas air yang tergolong tidak layak untuk digunakan sebagai sumber pemadaman di Kota Surakarta. Selain itu, saluran air hidran yang digunakan dalam pemenuhan kebutuhan pemadaman ini menjadi satu dengan saluran kebutuhan penggunaan air di Kota Surakarta. Sehingga pada jam-jam tertentu seperti pada saat waktu padat penggunaan air (seperti siang hari) mengakibatkan air dari sebagian hidran hanya mampu mengeluarkan sedikit dan membutuhkan waktu ber jamjam untuk mengisi penuh mobil tangki pemadam.

3.1.2 Hidran. Hidran merupakan sarana proteksi kebakaran yang berfungsi untuk mengeluarkan sumber air yang digunakan dalam pemadaman kejadian kebakaran. Tertera dalam Permen PU No 20/PRT/M/2009, jenis hidran sendiri terdapat dua jenis, yaitu hidran pilar dan hidran tanam [12]. Jumlah hidran di Surakarta yang didapatkan dari pengolahan data sebanyak 78 buah. Persebaran dan jangkauan hidran di Kota Surakarta dapat dilihat pada Gambar 3. 


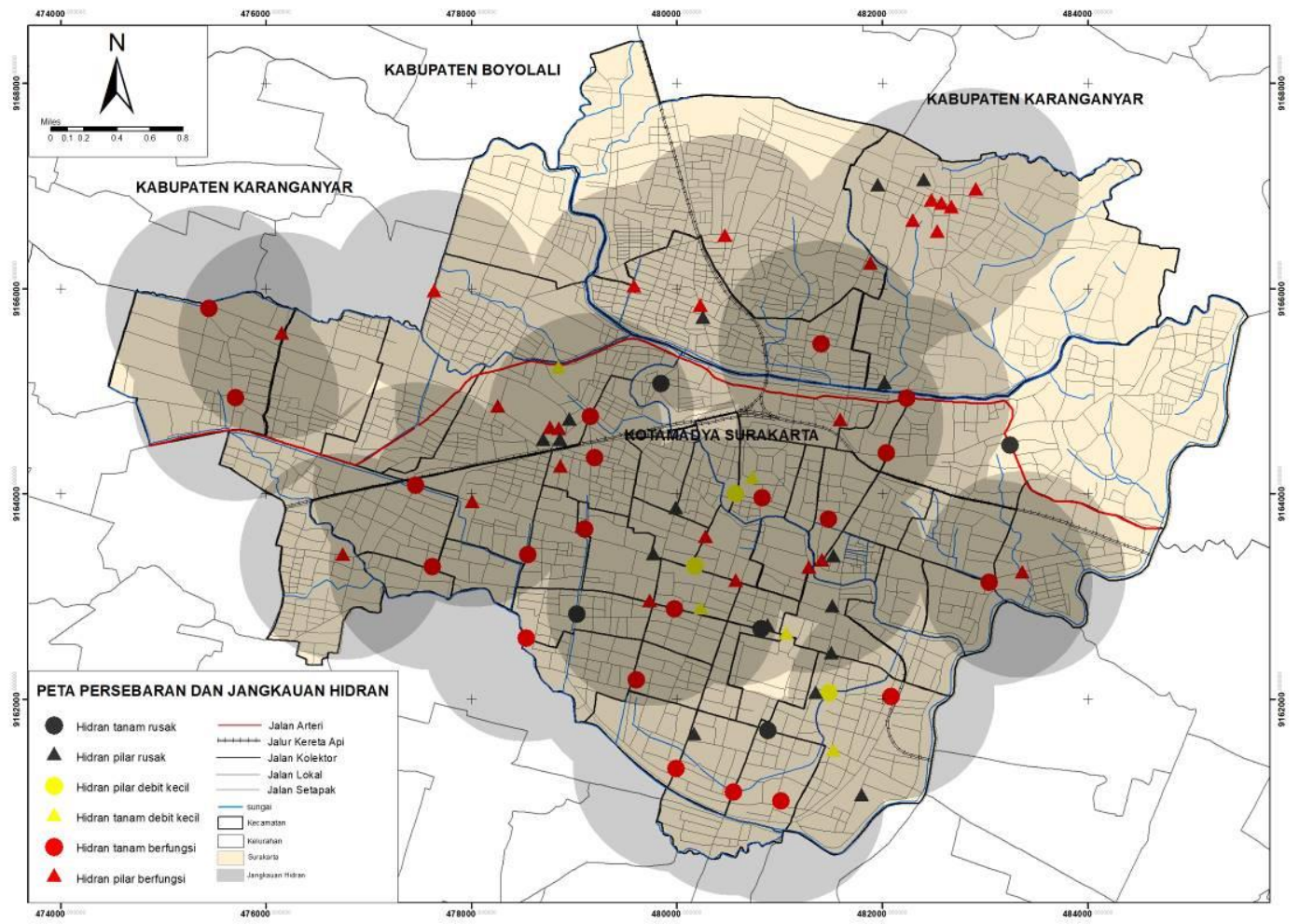

Gambar 3. Peta persebaran dan jangkauan hidran.

Dari total hidran tersebut, terdapat tiga fungsi dari masing-masing hidran, di antaranya 48 hidran berfungsi dengan baik ( 27 hidran pilar dan 21 hidran tanam), 8 hidran berfungsi dengan debit kecil (3 hidran pilar dan 5 hidran tanam), dan 22 hidran rusak/ tidak dapat digunakan (17 hidran pilar dan 5 hidran tanam). Berikut merupakan persentase kondisi dan jangkauan hidran yang dapat dilihat pada Gambar 4.

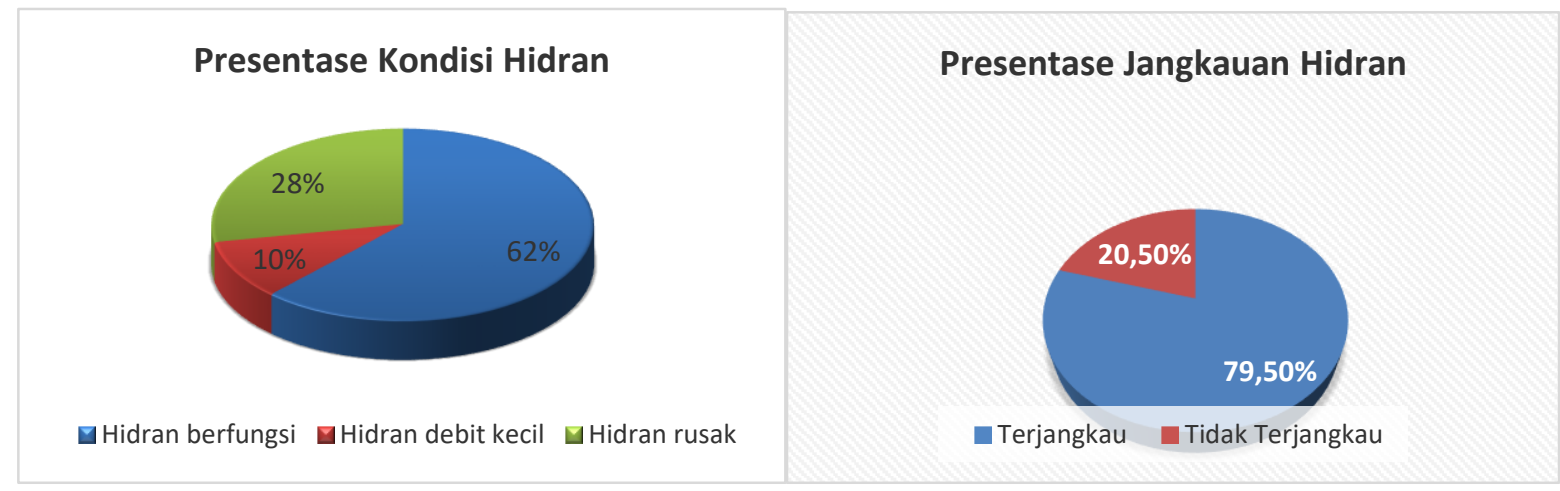

Gambar 4. Persentase kondisi dan jangkauan hidran.

Dari data tersebut diasumsikan bahwa hidran yang bisa digunakan sejumlah 48 buah (hidran yang berfungsi dengan baik) atau sekitar $61,5 \%$. Selain itu, menurut Damkar jangkauan hidran yang berfungsi dengan baik adalah sejauh $1 \mathrm{~km}$. Dari hasil analisis menggunakan buffer pada GIS didapatkan jangkauan hidran hampir menjangkau seluruh kawasan di Kota Surakarta dengan kisaran 3658 ha atau sekitar 79.5\% dari luas Kota Surakarta. 
3.1.3 Pos pemadam kebakaran. Sesuai yang tercantum dalam SNI 03-1733-2004, pos pemadam merupakan jenis sarana pelayanan pemerintahan, dan dalam kategori ini pos pemadam dinaungi oleh Dinas Pemadam Kebakaran. Pos pemadam berfungsi untuk memberikan aksi tanggap darurat ketika terdapat bencana terutama bencana kebakaran. Kota Surakarta memiliki empat unit pos pemadam di antaranya pos I di Kota Barat, pos II di Pedaringan, pos III di Gading, dan pos IV di Kantor BPBD Manahan (lihat Gambar 5). Menurut Permen PU No 20/PRT/M/2009, terdapat kelengkapan sarana dan peralatan operasional pada pos pemadam yang harus ada [12]. Dari hasil obervasi dan wawancara pada masing-masing pos pemadam, diketahui kelengkapan sarana dan peralatan pada masing-masing pos dapat dilihat pada Tabel 2 sebagai berikut.

Tabel 2. Sarana dan peralatan operasional pada masing-masing pos pemadam.

\begin{tabular}{|c|c|c|c|c|c|c|c|}
\hline \multirow[b]{2}{*}{$\begin{array}{c}\text { Pos } \\
\text { Pemadam }\end{array}$} & \multicolumn{3}{|c|}{ Fasilitas } & \multicolumn{4}{|c|}{ Peralatan Operasional } \\
\hline & $\begin{array}{l}\text { Mobil } \\
\text { Pompa }\end{array}$ & $\begin{array}{c}\text { Mobil } \\
\text { Tangki }\end{array}$ & $\begin{array}{c}\text { Tandon } \\
\text { Air }\end{array}$ & Pendobrak & Pemadam & Ventilasi & Penyelamat \\
\hline 1 & $\mathrm{~V}$ & $\mathrm{~V}$ & - & V & V & V & V \\
\hline 2 & V & V & - & - & V & V & V \\
\hline 3 & V & V & - & - & V & V & V \\
\hline 4 & - & V & - & - & V & - & $\mathrm{V}$ \\
\hline
\end{tabular}

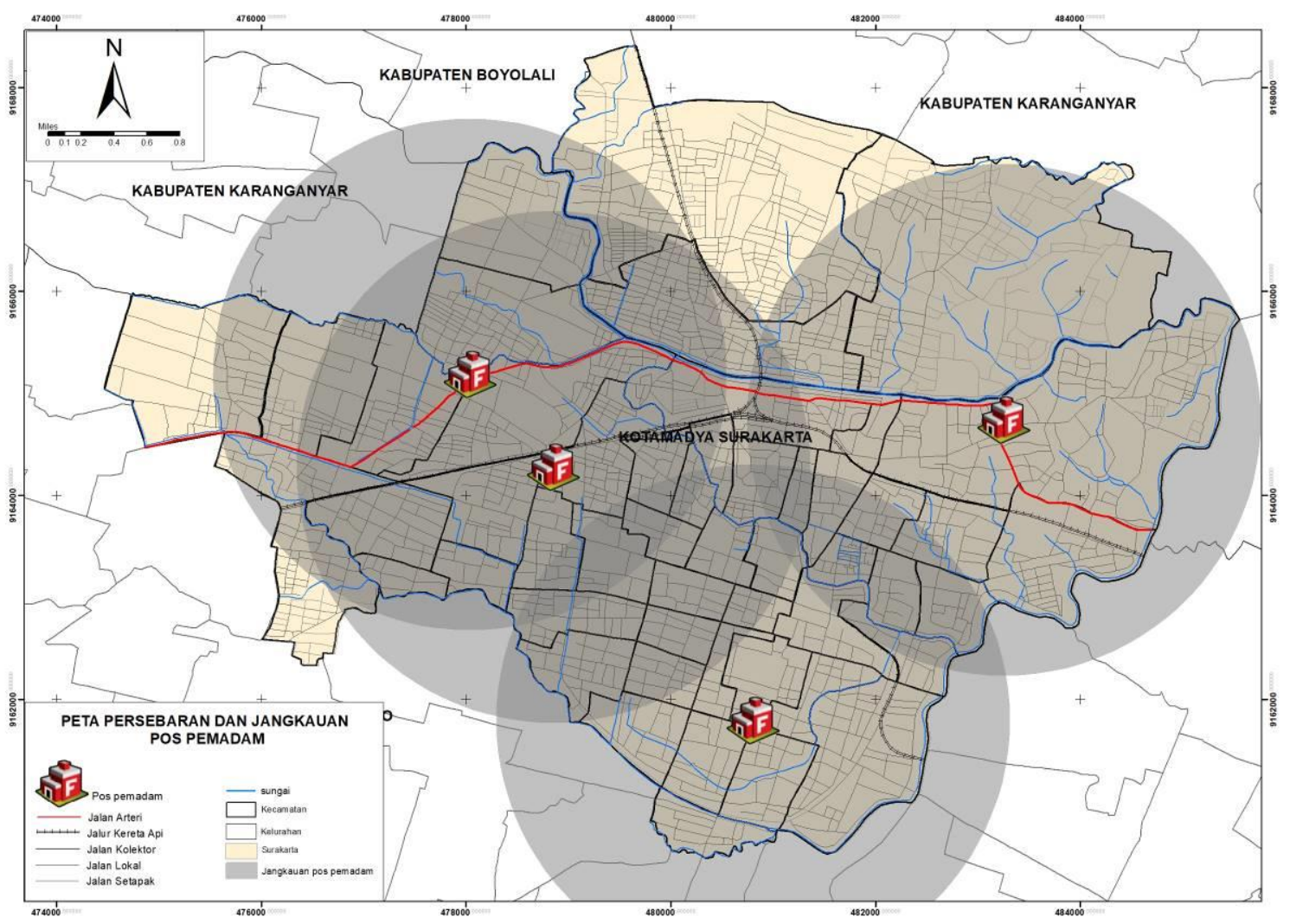

Gambar 5. Peta persebaran dan jangkauan pos pemadam.

Received: December 03, 2018; Accepted: December 20, 2018; Available online: July 15, 2021

Copyright @ 2021, REGION: Jurnal Pembangunan Wilayah dan Perencanaan Partisipatif 
Dari hasil pengolahan data di atas dapat dijabarkan pada pos 1 memiliki kelengkapan pada fasilitas penunjang dan peralatan operasional yang terbilang komplit. Pada pos pemadam dua dan tiga dapat dikatakan cukup. Sedangkan di pos 4, dapat dikatakan kurang dengan peralatan yang minim karena pos 4 juga baru dibentuk dan tempatnya pun juga belum pasti.

Selain itu, masing-masing pos pemadam memiliki jangkauan yang sudah ditetapkan pada Permen PU No 20/PRT/M/2009. Jangkauan pos pemadam sebesar 2,5 km dan maksimal jangkauan pos pemadam terhadap wilayah manajemen kawasan sebesar 7,5 km.

Dari hasil analisis dengan menggunakan buffer pada GIS, didapatkan luas Kota Surakarta yang terjangkau oleh pos pemadam sebesar 3704 ha atau sebesar $80.5 \%$. Selain itu, terdapat $19.5 \%$ atau sekitar 897 ha kawasan Surakarta yang belum terjangkau pos pemadam (lihat Gambar 6). Namun dapat dikatakan seluruh kawasan Kota Surakarta terjangkau pos pemadam bila disesuaikan dengan wilayah manajemen kawasan.

\section{Persentase Jangkauan Pos Pemadam}

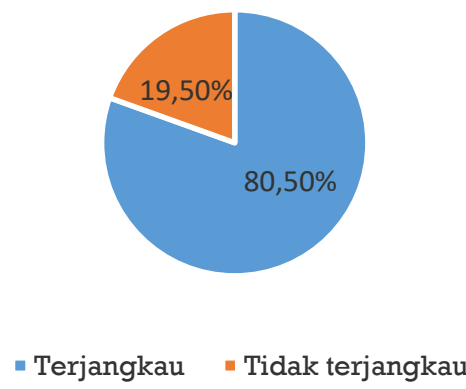

Gambar 6. Persentase jangkauan pos pemadam.

3.1.4 Aksesibilitas. Adapun hal-hal yang perlu diperhatikan dalam penjabaran aksesibilitas adalah waktu tanggap bencana yang dimiliki. Sesuai dengan penjabaran dalam Permen PU No 20/PRT/M/2009, waktu tanggap bencana yang diperlukan maksimal adalah 15 menit dengan ketentuan lima menit untuk penentuan lokasi dan persiapan, lima menit kedua untuk perjalanan ke lokasi, lima menit terakhir untuk menggelar peralatan di lokasi kejadian [12].

Dinas Pemadam Kebakaran pernah melakukan simulasi response time di lokasi RS Brayat Minulya pada tanggal 11 juli 2018. Total waktu yang dibutuhkan Dinas Pemadam Kebakaran untuk mencapai lokasi sebanyak 9 menit 38,5 detik dengan rincian kegiatan sebagai berikut.

- Pada jam 09.00 penerimaan informasi terkait kebakaran di lokasi RS Brayat Minulya. Lokasi ini termasuk jangkauan dari pos pemadam IV yang berada di Manahan. Namun karena kebakaran berada di lantai 3 RS Brayat, mengakibatkan perlunya pemberangkatan mobil tangga dari lokasi pos I Kota Barat menuju pos IV Manahan. Dengan kegiatan tersebut dan persiapan personil pada pos IV sehingga membutuhkan waktu sebanyak 58,4 detik. 
- Waktu tempuh dari Pos IV menuju RS Brayat adalah 2 menit 58,6 detik dengan ketentuan jarak pos ke lokasi kejadian 1,5 km dan kecepatan antara 40-60 km/jam.

- Waktu akses petugas pemadam kebakaran dari mobil pemadam menuju sumber api yang berada di lantai 3 membutuhkan waktu 1 menit 15,5 detik.

- Waktu persiapan peralatan pemadam kebakaran dan persiapan mobil tangga ke lantai 3 membutuhkan waktu 4 menit 26 detik.

Dengan penjabaran dari kegiatan response time Dinas Pemadam Kebakaran dapat dilakukan analisis dengan menggunakan GIS sehingga didapatkan peta sebagai berikut (lihat Gambar 7).

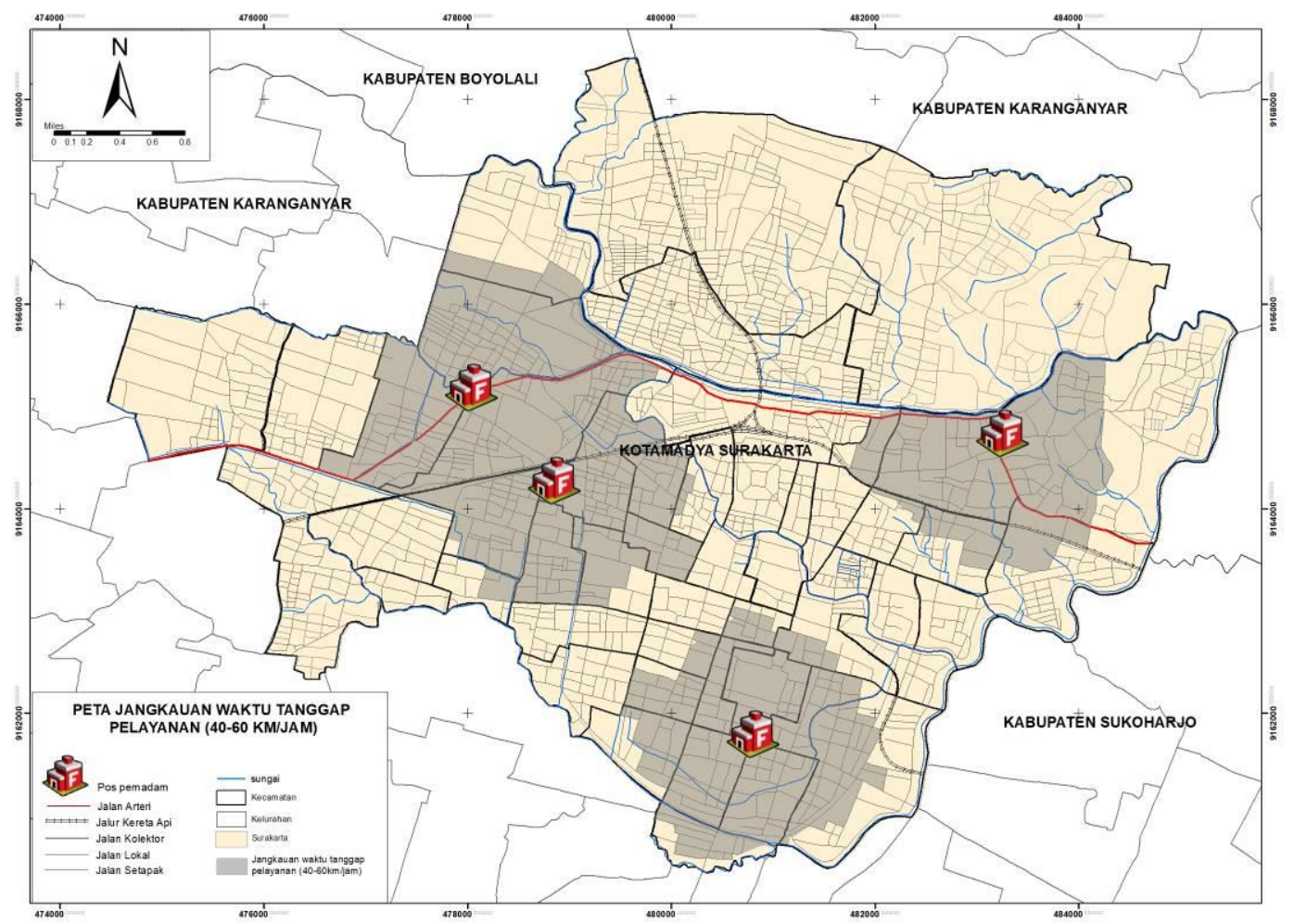

Gambar 7. Peta jangkauan waktu tanggap pelayanan pos pemadam.

Diketahui dengan penjabaran kegaitan di atas waktu tanggap yang diperoleh sekitar 9 menit 38,5 detik dengan penjabaran 58,4 penentuan lokasi dan persiapan, 2 menit 56,6 detik perjalanan menuju lokasi, dan 5 menit 41,4 detik menggelar peralatan di lokasi kejadian. Maka, jangkauan waktu tanggap hanya mencapai $38 \%$ yang disesuaikan dengan Permen PU No 20/PRT/M/2009.

\subsection{Mitigasi non struktural}

3.2.1 Penginformasian bencana. Penginformasian bencana memiliki definisi, yaitu mampu memberikan informasi terkait kejadian bencana yang ada. Informasi bencana ini ditujukan terutama pada kelengkapan yang terdapat pada peta. Peta yang dimaksud adalah peta risiko kebakaran dan peta persebaran lokasi sistem proteksi kebakaran kota. Dari hasil pencarian 
data, Kota Surakarta tidak memiliki peta risiko dan peta persebaran proteksi bencana. Oleh karena itu, dalam melakukan analisa tingkat risiko dan pencarian proteksi yang terpasang, pihak Dinas Pemadam Kebakaran menggunakan pengalaman mereka selama bertahun-tahun dalam menanggulangi kebakaran.

3.2.2 Peringatan dini. Fungsi dari peringatan dini adalah untuk memberikan informasi terkait kejadian bencana secara cepat baik itu untuk masyarakat sekitar ataupun kepada dinas yang bersangkutan. Di dalam ISDR [15], secara umum peringatan dini tertuju kepada dua obyek, yang pertama kepada masyarakat dan yang ke dua kepada pemerintah terkait. Bentuk peringatan dini di Kota Surakarta masih menggunakan sistem panggilan darurat. Pada masingmasing pos pemadam memiliki nomor darurat yang mampu dihubungi bila terjadi kejadian kebakaran. Namun bentuk peringatan dini yang ditujukan kepada masyarakat dalam bentuk sirine atau early warning system namun belum terpasang secara menyeluruh pada seluruh kawasan di Kota Surakarta. Hal itu dapat dibuktikan dengan sertifikat layak fungsi (SLF) dalam gedung. Pada dasarnya di tahun 2016-2017 di Surakarta hanya terdapat 4 gedung (Rumah Sakit Mata, Hotel Alila, Hotel Alaris, Rumah Sakit Hermina) yang memiliki sertifikat Layak Fungsi (SLF) dan 5 gedung lainnya sedang dalam proses pengajuan SLF (lihat Gambar 8). Hal tersebut menandakan bahwa pada sistem proteksi gedung yang berada di Kota Surakarta belum memiliki pengakuan secara resmi terkait dengan sistem proteksi kebakaran.

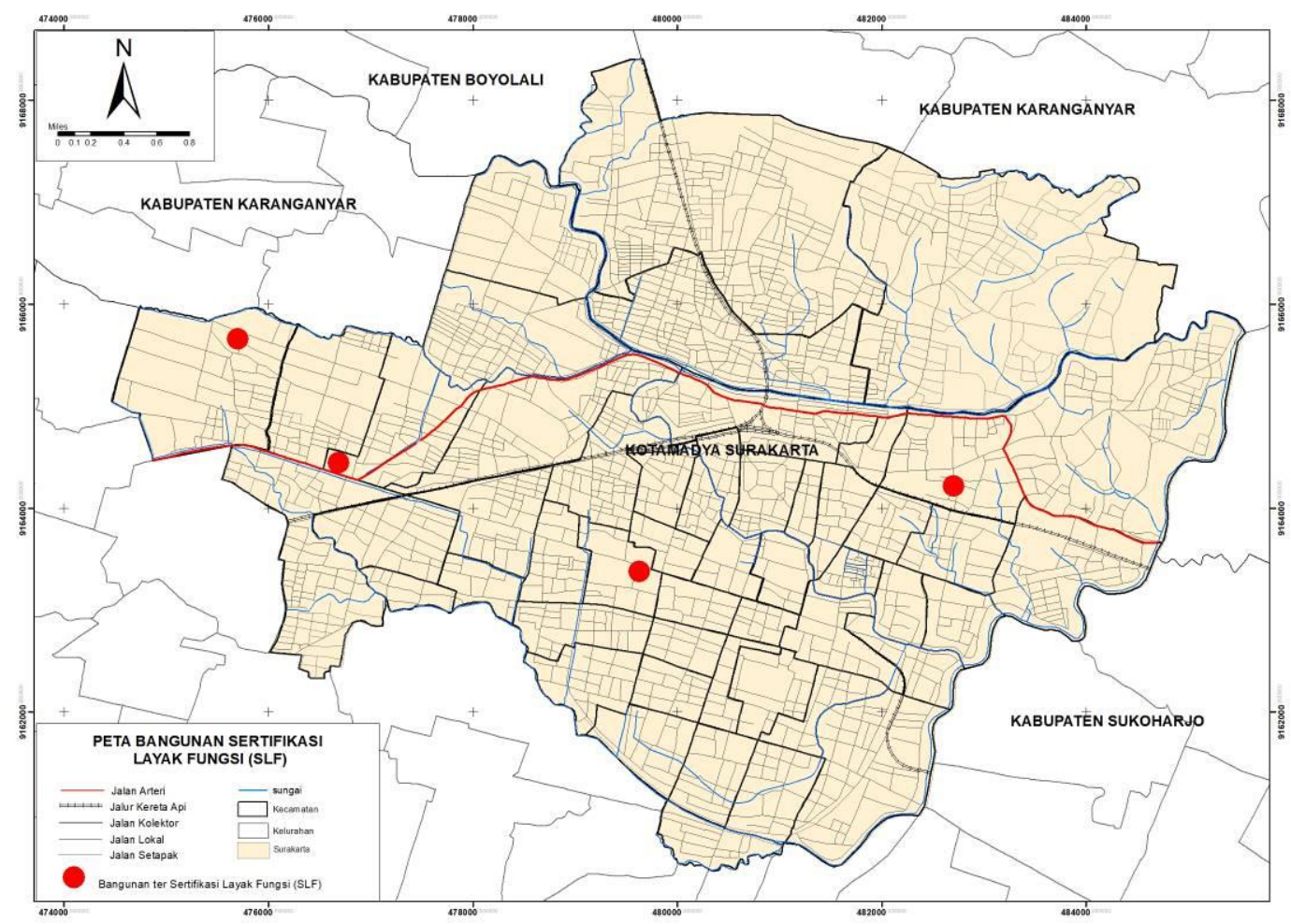

Gambar 8. Peta bangunan tersertifikasi layak fungsi. 


\subsection{Penilaian efektivitas komponen mitigasi bencana kebakaran}

Berdasarkan hasil analisis yang sudah dilakukan sebelumnya, langkah selanjutnya adalah menilai tingkat efektivitas dari komponen mitigasi bencana kebakaran yang berada di Kota Surakarta. Teknik yang dilakukan dalam menentukan tingkat efektivitas ini berupa analisis skoring. Dari hasil penilaian yang ada, didapatkan nilai skoing sebagai berikut (lihat Tabel 3).

Tabel 3. Penilaian efektivitas komponen mitigasi bencana kebakaran.

\begin{tabular}{|c|c|c|c|c|}
\hline Jenis Mitigasi & Variabel & Indikator & Keterangan & Nilai Skoring \\
\hline \multirow[t]{6}{*}{$\begin{array}{l}\text { Mitigasi } \\
\text { Struktural }\end{array}$} & Pasokan Air & Kualitas & $\begin{array}{l}\text { Terdapat sumber air alami } \\
\text { namun tidak mampu digunakan } \\
\text { ketika musim kemarau, dan atau } \\
\text { terdapat sumber buatan yang } \\
\text { digunakan tidak mencukupi }\end{array}$ & 2 \\
\hline & Hidran & Kuantitas & $\begin{array}{l}\text { Hidran berfungsi dengan baik } \\
\text { sebanyak 33,4\%-66,6\%. }\end{array}$ & 2 \\
\hline & & Kualitas & $\begin{array}{c}\text { Cakupan hidran terhadap } \\
\text { wilayah manajemen kawasan } \\
\text { sebanyak } 66,7 \%-100 \%\end{array}$ & 3 \\
\hline & Pos Pemadam & Kuantitas & $\begin{array}{l}\text { Tersedianya 2-3 peralatan } \\
\text { operasional dan } 2 \text { komponen } \\
\text { kendaraan operasional }\end{array}$ & 2 \\
\hline & & Kualitas & $\begin{array}{l}\text { Jangkauan pos pemadam } \\
\text { mencakup wilayah manajemen } \\
\text { kawasan sebesar } 66,7 \%-100 \%\end{array}$ & 3 \\
\hline & Aksesibilitas & Waktu & $\begin{array}{c}\text { Jangkauan waktu tanggap } \\
\text { sebanyak 33,4\%-66,6\%. }\end{array}$ & 2 \\
\hline \multirow[t]{3}{*}{$\begin{array}{l}\text { Mitigasi Non } \\
\text { Struktural }\end{array}$} & $\begin{array}{l}\text { Penginformasian } \\
\text { Bencana }\end{array}$ & Kualitas & $\begin{array}{l}\text { Tidak adanya peta dalam } \\
\text { penginformasian bencana }\end{array}$ & 1 \\
\hline & Peringatan Dini & Kualitas & $\begin{array}{l}\text { Masih kurangnya bentuk } \\
\text { peringatan dini }\end{array}$ & 2 \\
\hline & \multicolumn{3}{|c|}{ Total Skor } & 17 \\
\hline
\end{tabular}

Untuk mengetahui tingkatan efektivitas, perlu adanya perhitungan rumus sehingga diketahui interval dari masing-masing tingkat efektivitas yang dapat dilihat pada Tabel 4 sebagai berikut.

Tabel 4. Tingkatan efektivitas.

\begin{tabular}{cc}
\hline Tingkatan Efektivitas & Jumlah Skor \\
\hline Efektif & $18.68-24$ \\
Kurang Efektif & $13.34-18.67$ \\
Tidak Efektif & $8-13.33$ \\
\hline
\end{tabular}

Dari tabel penilaian tingkat efektivitas komponen mitigasi bencana kebakaran di atas, dapat disimpulkan bahwa nilai dari total komponen yang ada di Kota Surakarta sebesar 17 skor. Berdasarkan tabel tingkat efektivtias, komponen mitigasi yang dimiliki Kota Surakarta terdapat pada tingkat kurang efektif. Hal ini disebabkan karena terdapat beberapa skor pada bentuk mitigasi non struktural memiliki tingkatan yang sedang dan rendah. Dalam analisis yang telah dilakukan, Kota Surakarta belum memiliki peta risiko maupun peta persebaran proteksi kebakaran. Hal tersebut mengakibatkan belum diketahuinya tingkatan risiko bencana 
kebakaran di masing-masing penggunaan lahan yang ada dan kurang terarahnya dinas Pemadam Kebakaran dalam mencari lokasi-lokasi hidran maupun sistem proteksi lainnya yang dekat dengan lokasi kejadian kebakaran. Selain itu, pada sistem peringatan dini bentuk peringatan terhadap masyarakat masih minim, hanya terdapat empat bangunan yang memiliki Sertifikat Layak Fungsi (SLF) terkait proteksi kebakaran. Walaupun sudah terdapat sistem peringatan dini berupa panggilan darurat menuju pos pemadam tedekat, hal tersebut masih menggambarkan kurangnya tingkat peringatan dini dan mayoritas bangunan di Kota Surakarta terutama pada pusat-pusat kegiatan belum mengantongi Sertifikat Layak Fungsi (SLF). Maka dapat diartikan bahwa kelengkapan penanggulangan bencana kebakaran masih dapat dikatakan kurang efektif.

Selain itu, pada bentuk mitigasi struktural masih terdapat beberapa komponen yang tergolong dalam kategori kurang efektif. Di antaranya terdapat pasokan air yang belum mampu digunakan secara maksimal, jumlah hidran yang bisa digunakan hampir seimbang dengan jumlah hidran yang rusak atau tidak layak dipakai, kurang tersedianya peralatan dan kendaraan operasional di masing-masing pos pemadam, serta response time dari pos pemadam ke lokasi kejadian yang masih kurang dalam ketercapaian waktu tanggap bencana.

\section{Kesimpulan}

Komponen mitigasi kebakaran terbagi menjadi dua jenis, yaitu mitigasi struktural dan non struktural. Pada mitigasi struktural terdapat pasokan air, hidran, pos pemadam dan aksesibilitas. Sementara pada mitigasi non struktural terdapat penginformasian bencana dalam bentuk pemetaan dan peringatan dini. Penentuan nilai efektivitas didasarkan pada pengukuran keefektifan dalam mencapai suatu tujuan. Terdapat tiga indikator dalam menentukan pengukuran efektif, antara lain kualitas, kuantitas, dan waktu. Indikator ini digunakan untuk menilai masing-masing komponen mitigasi yang sesuai. Berdasarkan hasil analisis skoring pada masing-masing komponen, didapatkan tingkat efektivitas komponen mitigasi bencana di Kota Surakarta tergolong dalam tingkatan kurang efektif. Hal tersebut dikarenakan masih terdapatnya kuantitas, kualitas maupun waktu dari komponen mitigasi bencana yang masih dalam kategori rendah dan sedang. Seperti pada komponen mitigasi struktural yang berupa kualitas pasokan air, kuantitas atau jumlah hidran yang bisa digunakan, kuantitas atau perlengkapan pada masing-masing pos pemadam, dan waktu tanggap bencana yang masih dalam kategori sedang karena belum mampu memenuhi kebutuhan Kota Surakarta secara menyeluruh. Pada komponen mitigasi non struktural berupa penginformasian dalam bentuk peta dan peringatan dini masih dalam kategori sedang dan rendah karena belum adanya peta penginformasian dan peta persebaran proteksi. Selain itu, bentuk peringatan dini yang dimiliki Kota Surakarta masih kurang. Namun, pada kualitas hidran dan pos pemadam sudah dapat dikatakan baik karena pada jangkauan kedua sistem proteksi tersebut hampir menjangkau seluruh kawasan di Kota Surakarta.

\section{Referensi}

[1] Ramli S. Petunjuk Praktis Manajemen Kebakaran (Fire Management). Jakarta: PT. Dian Rakyat; 2010. 
[2] Badan Standarisasi Nasional. SNI 03-1745-2000 tentang Tata Cara Perencanaan, Pemasangan, dan Pengujian Sistem Deteksi dan Alarm Kebakara untuk Pencegahan Bahaya Kebakaran pada Bangunan Gedung 2000.

[3] Ariobowo M. Pengaruh Perkembangan Kota Singapura terhadap Angka Pengungkapan Penyelundupan Barang Palsu di Pelabuhan PSA Singapura Mahadika Ariobowo Departemen Hubungan Internasional, Fakultas IImu Sosial dan IImu Politik Universitas Diponegoro Jalan Prof . H . Soed 2017;3:206-13.

[4] Republik Indonesia. Peraturan Pemerintah No. 21 Tahun 2008 tentang Penyelenggaraan Penanggulangan Bencana 2008.

[5] Badan Penanggulangan Bencana Daerah (BPBD). Kejadian Bencana Tahun 2010-2016 2017.

[6] Dinas Pemadam Kebakaran Surakarta. Kejadian Bencana Kebakaran Tahun 20172017.

[7] Dinas Pemadam Kebakaran Surakarta. Radius Jangkauan Pelayanan Hidran Berfungsi dengan Baik 2018.

[8] Republik Indonesia. Undang-Undang No. 24 Tahun 2007 tentang Penanggulangan Bencana 2007.

[9] Sukamto. Manajemen Antisipasi Bencana. Yogyakarta: Graha Ilmu; 2015.

[10] Wiarto G. Tanggap Darurat Bencana Alam. Yogyakarta: Gosyen Publishing; 2017.

[11] Kusumasari B. Manajemen Bencana dan Kapabilitas Pemerintah Lokal. Yogyakarta: Gava Media; 2014.

[12] Republik Indonesia. Peraturan Menteri Pekerjaan Umum No. 20 Tahun 2009 tentang Pedoman Teknis Manajemen Proteksi Kebakaran di Perkotaan 2009.

[13] Darinsyah Y. Efektivitas Penggunaan Anggaran Pendapatan dan Belanja Daerah (APBD) dalam Program Pengentasan Kemiskinan di Kecamatan Bantan Kabupaten Bengkalis Tahun 2010-2012. JOM FISIP 2014;1:1-14.

[14] Badan Standarisasi Nasional. SNI 03-1733-2004 tentang Tata Cara Perencanaan Lingkungan Perumahan di Perkotaan 2004.

[15] ISDR. Membangun Sistem Peringatan Dini: Sebuah Daftar Periksa. Bonn: EWC III Konferensi Internasional Ketiga Tentang Peringatan Dini; 2006. 